\title{
DIAGNOSTIC EFFICACY OF RED BLOOD CELL INDICES IN DIAGNOSIS OF BETA THALASSEMIA TRAIT TAKING HAEMOGLOBIN ELECTROPHORESIS AS GOLD STANDARD
}

\author{
Sahar Rabbani, Muhammad Farooq, Samina Naeem, Nasir Uddin, Muhammad Abdul Naeem*, Shahneela Jabeen \\ Combined Military Hospital Lahore/National University of Medical Sciences (NUMS) Pakistan, *Armed Forces Institute of Transfusion/National University of \\ Medical Sciences (NUMS) Rawalpindi Pakistan
}

\begin{abstract}
Objective: To determine the diagnostic efficacy of haematological indices for the diagnosis of beta thalassemia trait taking haemoglobin electrophoresis as a gold standard.

Study Design: Cross sectional study.

Place and Duration of Study: Department of Haematology Combined Military Hospital Lahore, from Aug to Dec 2019.

Methodology: Two hundred and six anaemic patients 20-70 years of age of both genders were included in the study. Blood was collected from all the patients and complete blood count were generated through automated haematology analyser Sysmex KX-21. Based on the complete blood count parameters like mean cell volume, red blood cell count, red cell distribution width and mean cell haemoglobinthe haematological indices such as Mentzer, Ricerca, mean density of $\mathrm{Hb} /$ litre of blood, mean cell $\mathrm{Hb}$ density and red cell distributon width indices were calculated. The haemoglobin $\mathrm{A} 2$ band of $>3.5 \%$ on haemoglobin electrophoresis was taken as cut off for Beta thalassemia trait.

Results: Out of the 206 blood samples analysed, 120 (58\%) were labelled as Beta thalassemia trait after Hb electrophoresis and 86 cases had anemia due to other causes. Mentzer index established the highest sensitivity of $92.5 \%$ whereas RICERCA index established the highest specificity of $94.1 \%$. Mentzer and red cell distribution width indexhad highest diagnostic efficacy value up to $90.3 \%$.

Conclusion: We conclude that Mentzer and red cell distribution width index showed the highest diagnostic significance. The Mentzer index has the highest sensitivity whereas Ricerca index has the highest specificity. The red blood cell count, haemoglobin and mean cell volume are used to measure the Mentzer index and red cell distribution width index that showed consistent ability to provide definitive diagnosis regarding-thalassemia trait.
\end{abstract}

Keywords: Beta thalassemia trait, Haemoglobin electrophoresis, Haematological indices, Mentzer, mean density of $\mathrm{Hb} /$ litre of blood, Mean cell hb density, Red cell distribution width index and ricerca.

This is an Open Access article distributed under the terms of the Creative Commons Attribution License (https://creativecommons.org/licenses/by-nc/4.0/), which permits unrestricted use, distribution, and reproduction in any medium, provided the original work is properly cited.

\section{INTRODUCTION}

Two of the most common causes of microcytic hypochromic anemia worldwide are iron deficiency anemia (IDA) and beta thalassemia trait ( $\beta$ TT) with similar red blood cell indices and morphological findings ${ }^{1-3}$. It is important to differentiate between the two disorders so that unnecessary iron therapy can be avoided in $\beta \mathrm{TT}^{2}$. Thalassemia is an inherited haemoglobinopathy with impaired globin chain synthesis leading to ineffective haematopoiesis, $5 \%$ of the world's population have haemoglobin production defects with $7 \%$ being carriers. Thalassemia is a global health problem with Middle East, Southeast Asia and Mediterranean each contributing 10\% 9\% \& 8\% respectively ${ }^{4}$. Annually 5000 homozygous thalassemia patients are born in Pakistan and 5\% have the heterozygous beta thalassemia gene making it a common inherited haemoglobin disorder in the country ${ }^{4}$.

Estimation of complete blood counts is an initial

Correspondence: Dr Sahar Rabbani, Department of Haematology, Combined Military Hospital Lahore Pakistan

Received: 25 Feb 2020; revised received: 26 Jun 2020; accepted: 02 Jul 2020 investigation for diagnosis of haematological disorders. The difference between IDA and $\beta$ TT can be made on basis of complete blood count parameters, serum ferritin level and $\mathrm{HbA} 2$ concentration. The red blood cell indices determined by the automated blood analyzers give us a first indication of $\beta$ TT which are rapid and cost effective. These include red blood count, mean cell volume, mean cell haemoglobin, haemoglobin level and red cell distribution width ${ }^{5}$. Gold standard for diagnosis of $\beta$ TT includes different electrophoretic techniques including cellulose acetate/agargel electrophoresis and high performance liquid chromatography. These are very precise but time consuming and expensive, not readily available to poor communities $^{6,7}$.

It is important to discriminate IDA and $\beta$ TT with regard to their different management. In Pakistan due to financial constraints and high prevalence of thalassemia, mathematical indices provide a simpler solution for differential diagnosis ${ }^{8}$. These discriminating formulae are calculated from the various red blood cell indices with different cut off values, sensitivity and 
specificity. These can help in planning further workup and unnecessary tests can be avoided. Ideal index is the one with high sensitivity and high specificity 9 . Various studies have shown that these indices help in making probable diagnosis of BTT. These include Mentzer index, mean cell $\mathrm{Hb}$ density, mean density of $\mathrm{Hb} /$ litre of blood, Red cell distribution width index, Ricerca, Shine and Lal and England and Fraser index ${ }^{10}$.

The present study was done to assess the diagnostic efficacy of five indices that included: Mentzer index, Ricerca, mean density of $\mathrm{Hb}$ /Litre of blood, mean cell $\mathrm{Hb}$ density and red cell distribution width index.

\section{METHODOLOGY}

It was a cross-sectional study carried out at the department of haematology of Combined Military Hospital Lahore from August 2019 to December 2019. The sample size was calculated using diagnostic accuracy sample size calculator by taking statistics for sensitivity of Mentzer as $82.3 \%$, specificity as $98.7 \%$ (assumed as $95 \%)^{13}$, prevalence of $\beta$ TT as $50 \%{ }^{16}$, margin of error for sensitivity as $7.3 \%$ and specificity as $4.3 \%$ at 95\% confidence interval. The calculated sample size was 206. All the anaemic patients (having haemoglobin level $<10 \mathrm{~g} / \mathrm{dl}$ on $\mathrm{CBC}$ ) of age 20-70 years of either gender were included in the study using non-probability consecutive sampling technique. Patients who were critically ill and who had recent blood transfusion in the last 4 weeks were excluded from the study.

The ethics review committee (ref no. 135/2019) approval was sought before the conduct of study. Informed written consent was taken from all the patients or their guardians before data collection. The baseline information such as age, gender and address of the all eligible patients was recorded along with relevant history. Five (5) $\mathrm{mL}$ of blood was collected from all the patients into Di potassium ethylenediaminetetraactic acid (K2. EDTA) tube for haematological examination and processed on Sysmex-KX-21 for complete blood count. Haemoglobin electrophoresis was performed for haemoglobin A2 estimation. $\mathrm{HbA} 2>3.5 \%$ was taken as a cut off for $\beta$ TT diagnosis. Based on the complete blood count parameters like mean cell volume (MCV fL), red blood cell count (RBC), red cell distribution width (RDW) and mean cell haemoglobin $(\mathrm{MCH})$ the haematological indices were calculated and cut-off values 13 of each indices for $\beta$ TT (table-I).

SPSS-23 was used to analyse data. Mean and SD were calculated for numerical variables whereas frequency and percentages were calculated for categorical variables. Sensitivity, specificity, negative predictive value, positive predictive value and diagnostic accuracy were computed for all the haematological indices by taking $\mathrm{HbA} 2>3.5 \%$ as a cut off value for diagnosis of Beta thalassemia trait.

\section{RESULTS}

Age range of the patients was 20-70 years (Mean $25.26 \pm 13.26$ years). Majority of the patients were males $(66 \%)$ as compared to females $(34 \%)$. Out of the 206 blood samples analysed, $120(58.3 \%)$ were confirmed to have $\beta$ TT after $\mathrm{Hb}$ electrophoresis and 86 cases showed no band of $\mathrm{HbA} 2$ on electrophoresis (fig-1).

On mentzer 122 patients were diagnosed to have $\beta$ TT (59.2\%), on Ricerca 105 patients were diagnosed to have $\beta \mathrm{TT}(51 \%)$, on MDHL 99 patients were diagnosed to have $\beta$ TT ( $48.1 \%)$, on MCHD 123 patients were diagnosed to have $\beta$ TT $(59.7 \%)$ and on RDWI 118 patients were diagnosed to have $\beta$ TT $(57.3 \%)$ respectively (fig2).

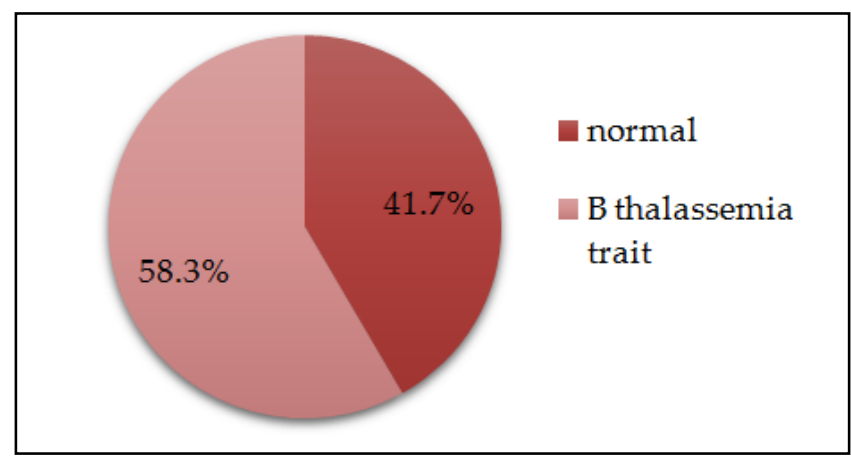

Figure-1: Frequency of beta thalassemia trait after haemoglobin electrophoresis.

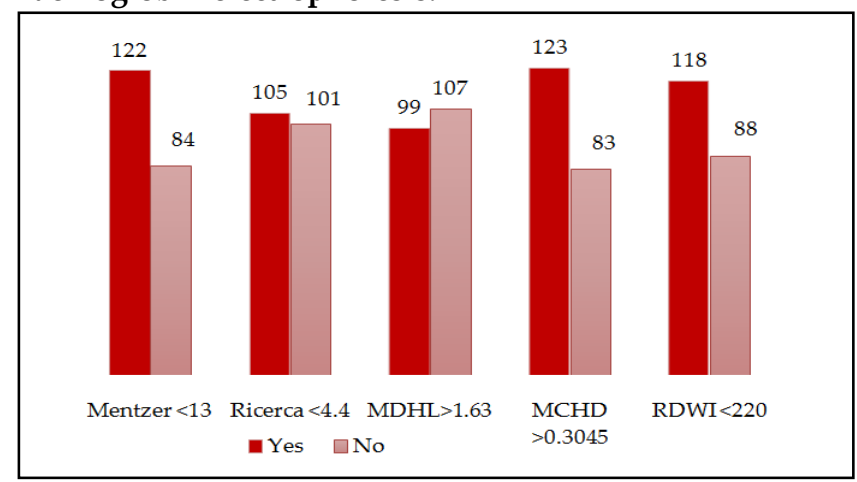

Figure-2: Findings of haematological indices for Beta thalassemia trait.

Mentzer index established the highest sensitivity of $92.5 \%$ whereas RICERCA index established the highest specificity of $94.1 \%$. Mentzer and RDWI indices had highest diagnostic efficacy value up to $90.3 \%$. None of the indices provided $100 \%$ values of sensitivity and specificity when compared with standard (table-II). 
Table-I: Mean cell haemoglobin the haematological indices were calculated and cut-off values for $\beta$ TT.

\begin{tabular}{l|c|c}
\hline Indices & Formula & $\begin{array}{c}\text { Cut-off Value for Beta } \\
\text { Thalassemia Trait Diagnosis }\end{array}$ \\
\hline Mentzer & Mean cell volume/Red blood cell & $<13$ \\
\hline Ricerca & Red cell distribution width/Red blood cell & $<4.4$ \\
\hline Mean density of Hb/litre of blood & (Mean cell Hb/Mean cell volume) x Red blood cell & $>1.63$ \\
\hline Mean cell Hb density & Mean cell Hb/Mean cell volume & $>0.3045$ \\
\hline Red cell distribution width index & $\begin{array}{c}\text { Mean cell volume } x \text { Red cell distribution } \\
\text { width/Red blood cell }\end{array}$ & $<220$ \\
\hline
\end{tabular}

Table-II: Diagnostic efficacy of hematological indices taking HBA2 $>3.5 \%$ as gold standard in diagnosis of beta thalassemia trait.

\begin{tabular}{|c|c|c|c|c|}
\hline \multirow{3}{*}{$\begin{array}{l}\text { Hematological Indices } \\
\text { Mentzer }<13\end{array}$} & \multicolumn{2}{|c|}{$\mathrm{HbA} 2>3.5 \%$} & \multirow{2}{*}{\multicolumn{2}{|c|}{ Statistics }} \\
\hline & \multirow[t]{2}{*}{ Yes } & \multirow[t]{2}{*}{ No } & & \\
\hline & & & Sensitivity & $92.5 \%$ \\
\hline Yes & 111 & 11 & Specificity & $87.2 \%$ \\
\hline \multirow[t]{3}{*}{ No } & 9 & 75 & Positive Predictive Value & $90.9 \%$ \\
\hline & \multirow{2}{*}{\multicolumn{2}{|c|}{$\mathrm{HbA} 2>3.5 \%$}} & Negative Predictive Value & $89.2 \%$ \\
\hline & & & Diagnostic Efficacy & $90.2 \%$ \\
\hline RICERCA $<4.4$ & Yes & No & Sensitivity & $83.3 \%$ \\
\hline Yes & 100 & 5 & Specificity & $94.24 \%$ \\
\hline \multirow[t]{3}{*}{ No } & 20 & 81 & Positive Predictive Value & $95.2 \%$ \\
\hline & \multirow{2}{*}{\multicolumn{2}{|c|}{$\mathrm{HbA} 2>3.5 \%$}} & Negative Predictive Value & $80.2 \%$ \\
\hline & & & Diagnostic Efficacy & $87.8 \%$ \\
\hline Mean Density of $\mathrm{Hb} /$ Litre of Blood (>1.63) & Yes & No & Sensitivity & $65 \%$ \\
\hline Yes & 78 & 21 & Specificity & $75.6 \%$ \\
\hline \multirow[t]{3}{*}{ No } & 42 & 65 & Positive Predictive Value & $78.8 \%$ \\
\hline & \multirow{2}{*}{\multicolumn{2}{|c|}{$\mathrm{HbA} 2>3.5 \%$}} & Negative Predictive Value & $60.7 \%$ \\
\hline & & & Diagnostic Efficacy & $69.4 \%$ \\
\hline Mean Cell Hb Density >0.3045 & Yes & No & Sensitivity & $74.2 \%$ \\
\hline Yes & 89 & 34 & Specificity & $60.5 \%$ \\
\hline \multirow[t]{3}{*}{ No } & 31 & 52 & Positive Predictive Value & $72.4 \%$ \\
\hline & \multirow{2}{*}{\multicolumn{2}{|c|}{$\mathrm{HbA} 2>3.5 \%$}} & Negative Predictive Value & $62.6 \%$ \\
\hline & & & Diagnostic Efficacy & $68.4 \%$ \\
\hline Red Cel Distribution Width Index $<220$ & Yes & No & Sensitivity & $90.8 \%$ \\
\hline Yes & 109 & 9 & Specificity & $89.5 \%$ \\
\hline No & 11 & 77 & Positive Predictive Value & $92.4 \%$ \\
\hline Negative Predictive Value & \multirow{2}{*}{\multicolumn{2}{|c|}{$87.5 \%$}} & & \\
\hline Diagnostic Efficacy & & & & \\
\hline
\end{tabular}

\section{DISCUSSION}

Annually, 5000 cases are found in Pakistan that are beta thalassaemia positive. Reflecting these numbers, the present study found $58 \%$ cases of $\beta T T$ after Haemoglobin electrophoresis. This emerges an important issue for diagnosing beta thalassemia with least cost and accurate diagnosis. Pakistan is a developing country and majority people belong to low socio economic status who cannot afford cost of Haemoglobin electrophoresis.

There are different haematological indices for diagnosing thalassemia. The Mentzer index is a ratio between MCV and RBC and having value of 13 is considered as thalassemia carriers ${ }^{11,12}$. The Ricerca index is ratio between red cell width and red blood cell count ${ }^{13}$. The MDHL index is the mean density of $\mathrm{Hb}$ /liter of blood and calculated as [(MCH/MVC) $x$ RBC]. The
MCHD index is the mean cell $\mathrm{Hb}$ density and calculate as ratio between $\mathrm{MCH}$ and $\mathrm{MCV}^{13}$. The RDWI index is red blood distribution width and calculated as [(MCV $x \mathrm{RDW} / \mathrm{RBC})]^{13}$.

Beyan et al, determined that sensitivity, specificity, positive and negative predictive value of Red Cell Indices were $84.8 \%, 88.9 \%, 91.8 \%$ and $80 \%$ respectively ${ }^{14}$. Though HbA2 estimation through electrophoresis, ferritin estimation and serum iron levels are still diagnostic tests for differentiating between beta thalassemia trait and iron deficiency anaemia still red blood cell count is found to be most predictive indicator ${ }^{15}$. The haematological indices are efficiently used in distinguishing beta thalassemia that helps save cost for other investigation ${ }^{5}$. Therefore, the different haematological indices also help us to understand those patients who are willing to maintain their follow-ups. 
There is paucity of data in this context in our region and prevalence of thalassemia in Pakistan needs us to determine best possible investigational tool in term of haematological indices. This study was planned with an aim of comparing diagnostic efficacy of different haematological indices in terms of Sensitivity, specificity, negative predictive value, positive predictive value by taking $\mathrm{HbA} 2>3.5 \%$ as cut off for diagnosis of $\beta$ TT.

In the year 2016, a study conducted in Pakistan found $29 \%$ of cases of $\beta$ TT positive ${ }^{17}$. In thalassemia, $\mathrm{MCV}$ equal to value $79 \mathrm{fl}$ and $\mathrm{MCH}$ is $27 \mathrm{pg}^{18}$. Many investigations have been carried out to determine sensitivity and specificity of hematologic indices in comparison with iron deficiency anaemia and youdens index ${ }^{14,17,19-21}$. However, the current study has entirely focused on beta thalassemia cases. The diagnostic efficacy of different haematological indices has been found out taking haemoglobin electrophoresis as gold standard and no other investigation tool has been used to compare the efficacy. The present study results showed that Mentzer and RDWI indices had highest diagnostic efficacy of $90 \%$. The ability of Mentzer index to diagnose actual cases is $92.5 \%$ and the ability to diagnose number of true negatives is $87.5 \%$ which explains that Mentzer index was helpful in diagnosing true positive cases rather true negatives. However, the results are in great disagreement with Siswandari et al. Study in which he concluded $36 \%$ sensitivity and $81 \%$ specificity of mentzer index ${ }^{22}$.

It is noteworthy that results showed contradiction to the previous study which proved mentzer index a very weak index to use for dignosis of beta thalesemia patients ${ }^{22}$. However, another study conducted by Sharma et al, showed lesser sensitivity (60\%) than specificity $(93.10 \%)$ which is also in discrepancy with current findings ${ }^{12}$. The inferior sensitivity might be due to the less number of red blood cells and presented higher diagnostic value in removing the likelihood of beta thalassemia. Nevertheless, the results for Mentzer index are in concurrence with Batebi et al, study having higher sensitivity $(94.5 \%)$ than specificity $(93.7 \%)^{23}$.

Literature suggest that the most usually used tests Mentzer index (MI) followed by discriminant factor $(\mathrm{DF})$ which is $\mathrm{MCV} \times(\mathrm{RDW} / \mathrm{Hb} \times 100)$ then Shine and Lal Index that is obtained by MCV $\times(\mathrm{MCH} / 100)$ then Srivastava Index (SI) calculated by $\mathrm{MCH} / \mathrm{RBC}$ and lastly RDWI24. Ullah et al, found that the red cell distribution width index was the most reliable in distinguishing between iron deficiency anaemia and beta thalassemia ${ }^{17}$. The RDWI is referred to as best screening replacement for where haemoglobin electrophoresis is unobtainable ${ }^{17}$. A study reported RDWI as most consistent index ${ }^{3}$. Another study showed Shine and Lal as reliable index for BTT though in a study Shine \& Lal index showed $100 \%$ sensitivity with specificity of 17 (39\%). Hence, we recommend to conducted separate studies on each haematological index to ascertain more accurate results.

\section{CONCLUSION}

According to our results, the Mentzer and RDWI indices showed the highest diagnostic significance. The Mentzer index has the highest sensitivity whereas RICERCA index established has the highest specificity. The RBC, haemoglobin and MCV counts are used to measure the Mentzer index and RDW index that showed consistent ability to provide definitive diagnosis regarding $\beta$-TT. These indices can help us in screening patients of $\beta$-TT in health units where the facility of haemoglobin electrophoresis is not available. The methodology is not only useful and inexpensive, but also highly feasible for a mass community screening of population where thalassemia trait is highly prevalent.

\section{RECOMMENDATION}

Medical students, house officers and general practitioners should be urged to apply these indices in routine practice and suspect Beta thalassemia trait so further segregation of patients can be done for workup by electrophoresis and people can make informed decisions regarding consanguineous marriages.

\section{CONFLICT OF INTEREST}

This study has no conflict of interest to be declared by any author.

\section{REFERENCES}

1. Zaghloul A, Al-bukhari TAMA, Bajuaifer N, Shalaby M, Pakistani HAA, Halawani $\mathrm{SH}$, et al. Introduction of new formulas and evaluation of the previous red blood cell indices and formulas in the differentiation between beta thalassemia trait and iron deficiency anemia in the Makkah region. Haematol 2016; 21(6): 351-58.

2. Jassin AN. Comparative behavior of red blood cells indices in iron deficiency anemia and $\beta$-thalassemia trait. Iraqi J Hematol 2016; 5(2): 183-86.

3. Jameel T, Baig M, Ahmed I, Hussain MB, Alkhamaly MBD. Differentiation of beta thalassemia trait from iron deficiency anemia by hematological indices. Pak J Med Sci 2017; 33(3): 66569.

4. Ullah Z, Khattak AA, Ali SA, Hussain J, Noor B, Bano R, et al. Evaluation of five discriminating indexes to distinguish BetaThalassemia Trait from Iron Deficiency Anaemia. JPMA 2016; 66(12): 1627-31.

5. Roth IL, Lachover B, Koren G, Levin C, Zalman L, KorenA. Detection of $\beta$-Thalassemia Carriers by Red Cell Parameters 
Obtained from Automatic Counters using Mathematical Formulas. Mediterr J Hemayol Infec Dis 2108; 10(1): 1-10.

6. Matos JF, Dusse LMS, Borges KBG, Castro RLVD, Vital WC, Carvalho MDG. A new index to discriminate between iron deficiency anemia and thalassemia trait. Brazilian J Hematol Hemotherap 2016; 38(3): 214-19.

7. Bhushan R, Shukla S, Singh D, Trivedi SS, Sharma S. Reliability of different rbc indices to differentiate between beta thalassemia trait and iron deficiency anemia during antenatal screening. World J Path 2018; 9(1): 1-5.

8. Jahangiri M, Rahim F, Malehi AS, Pezeshki SMS, Ebrahimi M. Differential Diagnosis of Microcytic Anemia, Thalassemia or Iron Deficiency Anemia: A Diagnostic Test Accuracy Meta-Analysis. Mod Med Lab J 2019; 3(1): 1-14.

9. Ahmad D, Ikram N, Bashir S, Yasin A. Discrimination Indices for Diagnosis of Beta $(\beta)$ Thalassemia Trait. J Raw Med Coll 2018; 22(1): 18-21.

10. Khan MI, Khan HN, Usman M. Beta thalassemia trait; diagnostic importance of haematological indices in detecting Beta thalassemia trait patients. Prof Med J 2018; 25(4): 545-50.

11. MAO. Types of anemias with low MCV using mentzer index and RBC count among patients seen in Basrah al-Sadir teaching hospital. Med J Babylon 2014; 11(2): 292-96.

12. Sharma AK, Mehta S, Sharma S. Utility of erythrocyte indices for screening of $\beta$-thalassemia trait in pregnant women attending antenatal clinic. Inter J Med Sci Educat 2016; 3(4): 331-37.

13. Vehapoglu A, Ozgurhan G, Demir AD, Uzuner S, Nursoy MA, Turkmen S, et al. Hematological indices for differential diagnosis of Beta thalassemia trait and iron deficiency anemia. Anemia 2014; 2014(1): 1-8.

14. Beyan C, Kaptan K, Ifran A. Predictive value of discrimination indices in differential diagnosis of iron deficiency anemia and beta thalassemia trait. European J Haematol 2007; 78(6): 524-26.
15. Thomas C, Thomas L. Biochemical markers and hematologic indices in the diagnosis of functional iron deficiency. Clinical Chemistry 2002 48(7): 1066-76.

16. Ehsani MA, Shahgholi E, Rahiminejad MS, Seighali F, Rashidi A. A new index for discrimination between iron deficiency anemia and beta-thalassemia minor: results in 284 patients. Pak J Biological Sci 2009; 12(5): 473-75.

17. Ullah Z KA, Ali SA, Hussain J, Noor B, Bano R, Mahsud MA. Evaluation of five discriminating indexes to distinguish BetaThalassemia Trait from Iron Deficiency Anaemia. J Pak Med Assoc 2016; 66(12): 1627-31.

18. Angastiniotis M, Eleftheriou A, Galanello R, Harteveld CL, Petrou M, Synodinos JT, et al. Prevention of Thalassaemia and Other Haemoglobin Disorders. Volume 1: Principles. 2nd ed. Nicosia (Cyprus). Thalassemia Int Federation 2013 Avalibal at Internet. https:// pubmed.ncbi.nlm.nih.gov/24672827/.

19. Demir A YN, Fisgin T, Duru F,Kara AR. Most reliable indices in differentiation between thalassemia trait and iron deficiency anemia. Pedia Int 2002; 44(6): 12-16.

20. Bessman JD, Feinstein DI. Quantitative anisocytosis as a discriminant between iron deficiency and thalassemia minor. Blood 1979; 53(2): 288-93.

21. Rahim F, Keikhaei B. Better differential diagnosis of iron deficiency anemia from beta-thalassemia trait. Turk J Hematol 2009; 26(3): 138-45.

22. Siswandari W, Rujito L, Indriani V, Djatmiko W, editors. Mentzer Index Diagnostic Value in Predicting Thalassemia Diagnosis. IOP Conference Series: Earth Environmental Sci 2019; 1(1): 1-7.

23. Batebi A, Pourreza A, Esmailian R. Discrimination of beta-thalassemia minor and iron deficiency anemia by screening test for red blood cell indices. Turkish J Med Sci 2012; 42(2): 275-80.

24. Brancaleoni V, Pierro ED, Motta I. Laboratory diagnosis of thalassemia. Int J Laborat Hematol 2016; 38(1): 32-40. 